\section{Structure of Sch 528647: A New Antitumor Antibiotic Related to Fumagillin}

\author{
Min Chu, * Ronald Mierzwa, ling He, Ling Xu, \\ Mahesh Patel, Dinesh Patel ${ }^{\dagger}$ and \\ TZE-Ming ChAN \\ Schering-Plough Research Institute, \\ 2015 Galloping Hill Road, Kenilworth, \\ New Jersey 07033-0539, USA \\ ${ }^{\dagger}$ Themis Chemical Ltd. \\ 11/12 Udyognagar S. V. Road, Goregaon (West), \\ Mumbai 400104, India
}

(Received for publication July 16, 2001)

Fumagillin (1) was originally isolated from Aspergillus fumigatus $^{1)}$ as an antiparasitic, ${ }^{2)}$ and belongs to the sesquiterpene family of compounds. In later biological studies, fumagillin and its analogs were reported as highly potent angiogenesis inhibitors, which inhibit endothelial cell proliferation in vitro and tumor-induced angiogenesis in vivo. ${ }^{3 \sim 5)}$ Methionine aminopeptidase-2 (MetAP-2), the specific enzyme was recently discovered to be the molecular target of fumagillin. ${ }^{6.7)}$ The binding mode of fumagillin to the enzyme was further revealed by X-ray crystallographic analysis. $^{8)}$ Furthermore, a semisynthetic analog of fumagillin, TNP-470 (AGM-1470), is currently in phase II clinical trials for the treatment of patients with a variety of cancers, including Kaposi's sarcoma, breast, cervical, lung and renal cancer. ${ }^{9 \sim 13)}$ In order to provide pure material for biological studies in our anti-cancer program, as well as to search for some new analogs, an isolation project of fumagillin and related compounds was launched. In the process of large-scale preparation of fumagillin, Sch 528657 (2), a novel metabolite closely related to fumagillin was discovered from Aspergillus fumigatus as shown in Fig. 1. Herewith, we wish to report on the isolation, structure elucidation and biological activity of $\mathbf{2}$.

The crude ethyl acetate extract from 100 liters fermentation broth was chromatographed on silica gel column eluting with hexane and ethyl acetate $(1: 1)$ to obtain the enriched mixture of $\mathbf{1}$ containing a small amount of $2(\sim 2 \%)$. The mixture was further purified by reversed phase HPLC under following conditions: YMC-ODS preparative column, S- $10 \mathrm{P}, 120 \AA, 250 \times 50 \mathrm{~mm}$ with a guard column $50 \times 50 \mathrm{~mm} ; 5 \sim 50 \%$ acetonitrile in $\mathrm{NH}_{4} \mathrm{OAc}$
$(10 \mathrm{~mm}$, as is $\mathrm{pH})$ with a linear gradient for 20 minutes, then $50 \sim 100 \%$ acetonitrile $/ \mathrm{NH}_{4} \mathrm{OAc}$ for 15 minutes, and followed by a $100 \%$ acetonitrile holding for 10 minutes; $50 \mathrm{ml} /$ minute flow rate; $U V$ detection at $390 \mathrm{~nm}$. Pure 2 was obtained as a yellow solid ( $16 \mathrm{mg}), \mathrm{m} . \mathrm{p} .=144 \sim 146^{\circ} \mathrm{C}$, $[\alpha]_{\mathrm{D}}^{25}-12.18^{\circ}(\mathrm{c} 0.1, \mathrm{MeOH})$.

The molecular weight of 2 was determined to be $442 \mathrm{Da}$ based on LC-MS data that showed the protonated molecular ion at $m / z 443(\mathrm{M}+\mathrm{H})^{+}$and a small water adduct ion at $\mathrm{m} / \mathrm{z}$ $460\left(\mathrm{M}+\mathrm{H}_{2} \mathrm{O}\right)^{+}$in the positive atmospheric pressure chemical ionization (+APCI) mode. This was also confirmed by observation of $m / z 441(\mathrm{M}-\mathrm{H})^{-}$in the negative APCI mode. The molecular formula was deduced by elemental analysis as $\mathrm{C}_{26} \mathrm{H}_{34} \mathrm{O}_{6}$ (Anal: $\mathrm{C}, 70.52 ; \mathrm{H}, 7.58$; calcd for $\left.\mathrm{C}_{26} \mathrm{H}_{34} \mathrm{O}_{6}: \mathrm{C}, 70.59 ; \mathrm{H}, 7.69\right)$. The UV spectral data of 2 showed a typical polyene pattern with maximum absorptions at 240 (72), 320 (sh. 1012), 335 (1478), 358 (1338) nm. As listed in Table 1 and 2, the ${ }^{1} \mathrm{H}$ and ${ }^{13} \mathrm{C}$ NMR spectra of $\mathbf{2}$ were strikingly similar to fumagillin. In the ${ }^{13} \mathrm{C}$ NMR spectrum of $\mathbf{2}$, the olefinic methylene and quaternary carbon signals at 110.83 and $146.78 \mathrm{ppm}$ indicated a terminal double bond formation in comparison with the spiro-epoxide carbon resonances at 51.66 and $60.28 \mathrm{ppm}$ in 1. The ${ }^{1} \mathrm{H}$ NMR data of 2 were consistent with the ${ }^{13} \mathrm{C}$

Fig. 1. Structures of fumagillin and Sch 528647 .

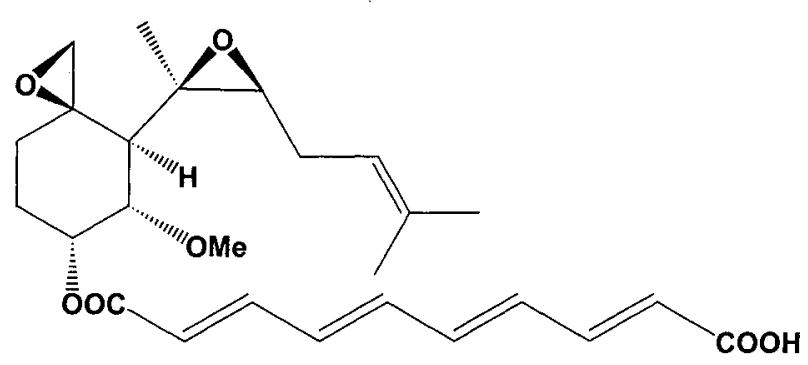

Fumagillin (1)

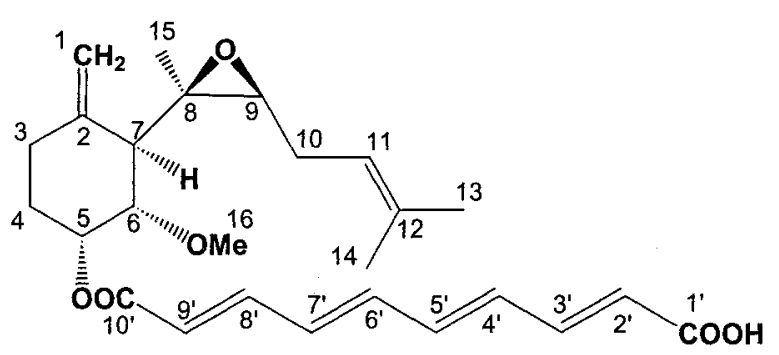

Sch 528647 (2)

* Corresponding author:min.chu@spcorp.com 
Table 1. ${ }^{1} \mathrm{H}$ NMR spectral data of $\mathbf{1}$ and $\mathbf{2}^{\mathrm{a}}$.

\begin{tabular}{|c|c|c|c|c|c|}
\hline \# & 1 & 2 & \# & 1 & 2 \\
\hline $1 \mathrm{a}$ & $2.56 \mathrm{~d}, J=5^{b}$ & $4.90 \mathrm{~s}$ & 14 & $1.65 \mathrm{~s}$ & $1.64 \mathrm{~s}$ \\
\hline $1 b$ & $2.97 \mathrm{~d}, J=5$ & $4.71 \mathrm{~s}$ & 15 & $1.17 \mathrm{~s}$ & $1.27 \mathrm{~s}$ \\
\hline 3 & $1.11,2.10 \mathrm{~m}, \mathrm{~m}$ & $2.18,2.29 \mathrm{~m}, \mathrm{~m}$ & 16 & $3.37 \mathrm{~s}$ & $3.33 \mathrm{~s}$ \\
\hline 4 & $1.90 \mathrm{~m}$ & $1.57,1.93 \mathrm{~m}, \mathrm{~m}$ & 2 & $6.02 \mathrm{~d}, \mathrm{~J}=15$ & $6.01 \mathrm{~d}, \mathrm{~J}=15$ \\
\hline 5 & $5.67 \mathrm{~m}$ & $5.54 \mathrm{~m}$ & $3^{\prime}$ & $7.31 \mathrm{dd}, \mathrm{J}=12,15$ & $7.28 \mathrm{dd}, \mathrm{J}=12,15$ \\
\hline 6 & $3.67 \mathrm{dd}, J=3,10$ & $3.40, \mathrm{dd}, J=3,10$ & $4^{\prime}$ & $6.65 \mathrm{t}, \mathrm{J}=12$ & $6.64 \mathrm{t}, \mathrm{J}=12$ \\
\hline 7 & $1.98 \mathrm{~d}, \mathrm{~J}=10$ & $2.26 \mathrm{~d}, \mathrm{~J}=10$ & 5 & $6.79, \mathrm{t}, \mathrm{J}=12$ & $6.76 \mathrm{t}, \mathrm{J}=12$ \\
\hline 9 & $2.58 \mathrm{t}, J=6$ & $2.61 \mathrm{t}, J=6$ & $6^{\prime}$ & $6.82 \mathrm{t}, \mathrm{J}=12$ & $6.81 \mathrm{t}, \mathrm{J}=12$ \\
\hline 10 & $2.22 \mathrm{~m}$ & $2.28 \mathrm{~m}$ & 7 & $6.65 \mathrm{t}, \mathrm{J}=12$ & $6.64 \mathrm{t}, \mathrm{J}=12$ \\
\hline 11 & $5.24 \mathrm{t}, \mathrm{J}=8$ & $5.23 \mathrm{t}, \mathrm{J}=8$ & 8 & $7.39 \mathrm{dd}, \mathrm{J}=12,15$ & $7.36 \mathrm{dd}, \mathrm{J}=12,15$ \\
\hline 13 & $1.72 \mathrm{~s}$ & $1.70 \mathrm{~s}$ & 9 & $6.06 \mathrm{~d}, \mathrm{~J}=15$ & $6.04 \mathrm{~d}, \mathrm{~J}=15$ \\
\hline
\end{tabular}

a. Recorded at $400 \mathrm{MHz}$ in acetone $-\mathrm{d}_{6}$

b. Coupling constants in $\mathrm{Hz}$

Table 2. ${ }^{13} \mathrm{C}$ NMR spectral data of 1 and $2^{\mathrm{a}}$.

\begin{tabular}{|c|c|c|c|c|c|}
\hline$\#$ & 1 & 2 & $\#$ & 1 & 2 \\
\hline 1 & $51.66 \mathrm{t}$ & $110.83 t$ & 14 & $18.09 q$ & $18.07 q$ \\
\hline 2 & $60.28 \mathrm{~s}$ & $146.78 \mathrm{~s}$ & 15 & $14.59 q$ & $14.09 \mathrm{q}$ \\
\hline 3 & $30.23 t$ & $31.32 \mathrm{t}$ & 16 & $56.77 q$ & $56.73 q$ \\
\hline 4 & $26.50 \mathrm{t}$ & $29.03 \mathrm{t}$ & $1^{\prime}$ & $168.25 \mathrm{~s}$ & 168.95 br.s \\
\hline 5 & $67.75 \mathrm{~d}$ & $68.25 d$ & 2 & 124.87 br.d & 125.43 br.d \\
\hline 6 & $80.40 \mathrm{~d}$ & $81.46 \mathrm{~d}$ & $3^{\prime}$ & $144.23 d$ & $144.06 \mathrm{~d}$ \\
\hline 7 & $49.16 \mathrm{~d}$ & $53.16 \mathrm{~d}$ & $4^{\prime}$ & $134.85 d$ & $134.34 \mathrm{~d}$ \\
\hline 8 & $59.08 \mathrm{~s}$ & $60.33 \mathrm{~s}$ & 5 & $139.83 d$ & $139.69 \mathrm{~d}$ \\
\hline 9 & $60.94 \mathrm{~d}$ & $61.45 \mathrm{~d}$ & $6^{\prime}$ & $140.53 d$ & $140.66 \mathrm{~d}$ \\
\hline 10 & $28.20 t$ & $28.47 t$ & $7^{\prime}$ & $134.99 \mathrm{~d}$ & $135.12 \mathrm{~d}$ \\
\hline 11 & $120.40 d$ & $120.45 d$ & $8^{\prime}$ & $144.74 d$ & $144.87 d$ \\
\hline 12 & $134.85 \mathrm{~s}$ & $134.53 \mathrm{~s}$ & $9^{\prime}$ & $123.79 d$ & $123.62 \mathrm{~d}$ \\
\hline 13 & $25.92 \mathrm{q}$ & $25.90 q$ & $10^{\prime}$ & $166.44 \mathrm{~s}$ & $166.65 \mathrm{~s}$ \\
\hline
\end{tabular}

a. Recorded at $100 \mathrm{MHz}$ in acetone $-\mathrm{d}_{6}$

b. Multiplicity was determined by APT and DEPT data. 
Fig. 2. HMQC-TOCSY data of 2 .<smiles>C=C1CCC(OC)C(OC)C1C(C)OC</smiles><smiles>COC(C)CC=C(C)C</smiles>

Fig. 3. Some important $\mathrm{HMBC}$ data of 2 .

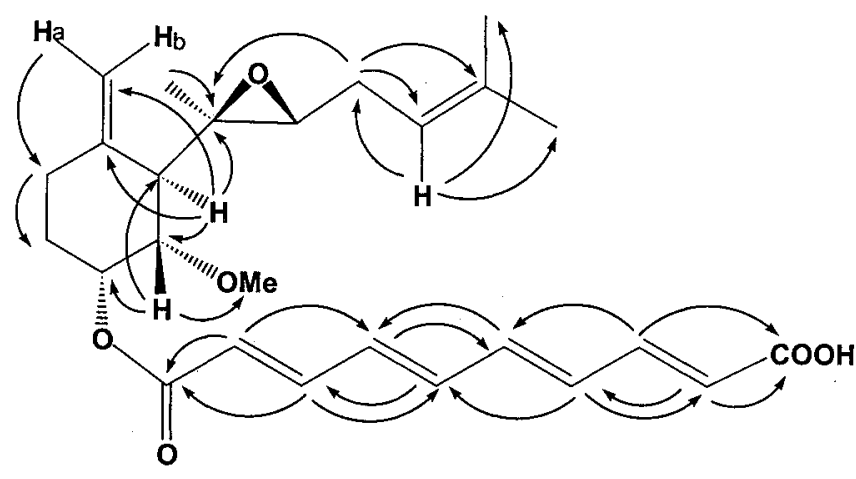

NMR data showing two vinyl singlets at 4.71 and $4.90 \mathrm{ppm}$ instead of the two epoxide doublets at 2.56 and $2.97 \mathrm{ppm}$ in 1. Extensive 2D-NMR experiments were carried out in order to elucidate the structure of 2 . Three fragments A, B and $\mathrm{C}$ were further established based on HMQC-TOCSY data as shown in Fig. 2. The assignments of protons and carbons were completed by the analysis of HMBC data as depicted in Fig. 3. The relative stereochemistry of $\mathbf{2}$ was determined by NOESY experiments, which revealed its similarity to fumagillin as shown in Fig. 4.

Compound 2 exhibited fairly potent antitumor activity against melanoma cells (SKMEL-5 cells) in the soft agar assay with an $\mathrm{IC}_{50}=250 \mathrm{nM}$. However, compound 1 elicited better potency with an $\mathrm{IC}_{50}=8 \mathrm{nM}$. This result of a $>31$-fold potency decrease strongly suggested that the
Fig. 4. NOSEY data of $\mathbf{2}$.

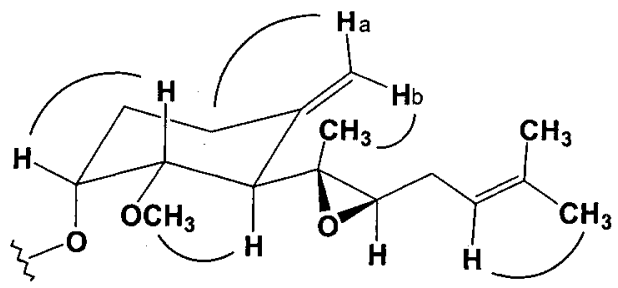

spiro-epoxide functionality plays an important role for antitumor activity.

Soft agar assay: Dilutions of compounds are made in DMSO and applied to a mixture of agarose and complete media to form the bottom layer. The bottom layer is then placed into specific wells and left to solidify. SKMEL-5 cells are prepared at a concentration of 5000 cells/well. Additional dilutions of compounds are made and cells are added to this agarose/media mixture. This top mixture is placed into specific wells and left to solidify before placing to a $37^{\circ} \mathrm{C}$ incubator for 3 weeks. Cells are then strained with MTT $(1 \mathrm{mg} / \mathrm{ml})$ and scanned for colony counts. Total area is measured and calculated vs. compound concentration.

\section{Acknowledgements}

Authors are grateful to Mr. E. MAXWell and Dr. B. Dasmahapatra for biological data, Mr. G. TorraCA and S. MitTELmAn for elemental analysis data, and Ms. D. SCOTT for preparing the manuscript.

\section{References}

1) Hanson, F. R. \& T. E. Eble: An antiphagen agent isolated from Aspergillus sp. J. Bacteriol. 58: 527 531, 1949

2) Takeda Chemical Industries: Control of microorganism infestation in fish by fumagillin. Japan Patent: 43,204, 1982

3) IngBer, D. E.; T. Fujita, S. Kishimoto, K. Sudo, T. KANAMARU, H. BREM \& J. FolKMAN: Synthetic analogues of fumagillin that inhibit angiogenesis and suppress tumor growth. Nature 348: 555 557, 1990

4) INGBER, D. E.: Extracellular matrix as a solid-state regulator in angiogenesis: identification of new targets for anticancer therapy. Seminar in Cancer Biol. 3: 57 63, 1992

5) Folkman, J. \& D. E. INGBer: Inhibition of angiogenesis. Seminar in Cancer Biol. 3: 89 96, 1992

6) Sin, N.; L. MENG, M. Q. WANG, J. J. WEN, W. B. 
Bornmann \& C. M. CRews: The anti-angiogenic agent fumagillin covalently binds and inhibits the methionine aminopeptidase, Met AP-2. Proc. Natl. Acad. Sci. USA 94: 6099 6103, 1997

7) Griffith, E. C.; Z. Su, S. Niwayama, C. A. Ramsay, Y.-H. Chang \& J. O. LIU: Molecular recognition of angiogenesis inhibitors fumagillium and ovalicin by methionine aminopeptidase-2. 95: 15183 15188, 1998

8) Liu, S.; J. Widom, C. W. Kemp, C. M. Crews \& J. ClaRdY: Structure of human methionine aminopeptidase-2 complexed with fumagillin. Science 282: 1324 1327, 1998

9) Kumar, C. C. \& L. ARmstrong: Tumor-induced angiogenesis: a novel target for drug therapy? Emerging Drugs 2: 175 190, 1997

10) Stradler, W. M.; T. Kuzel, C. Shapiro, J. Sosman, J.
Clark \& N. J. Vogelzang: Multi-institutional study of the angiogenesis inhibitor TNP-470 in metastatic renal carcinoma. J. Clinic. Oncol. 17: 2542 2545, 1999

11) Zgodzinski, W.; G. WALlneR \& A. DABRowsKI: Angiogenesis inhibitors: new anticancer strategy. Polish J. Pharm. 51: 455 462, 1999

12) Moore, J. D.; B. J. Dezube, P. Gill, X. J. Zhou, E. P. Acosta \& J. P. Sommadossi: Phase I dose escalation pharmacokinetics of $O$-(chloroacetylcarbamyol) fumagillol (TNP-470) and its metabolites in AIDS patients with Kaposi's saracoma. Cancer Chemo. Pharm. 46: $173 \sim 179,2000$

13) KRUGER, E. A. \& W. D. FIGG: TNP-470: an angiogenesis inhibitor in clinical development for cancer. Expert Opinion on Invest. Drugs. 9: 1383 1396, 2000 